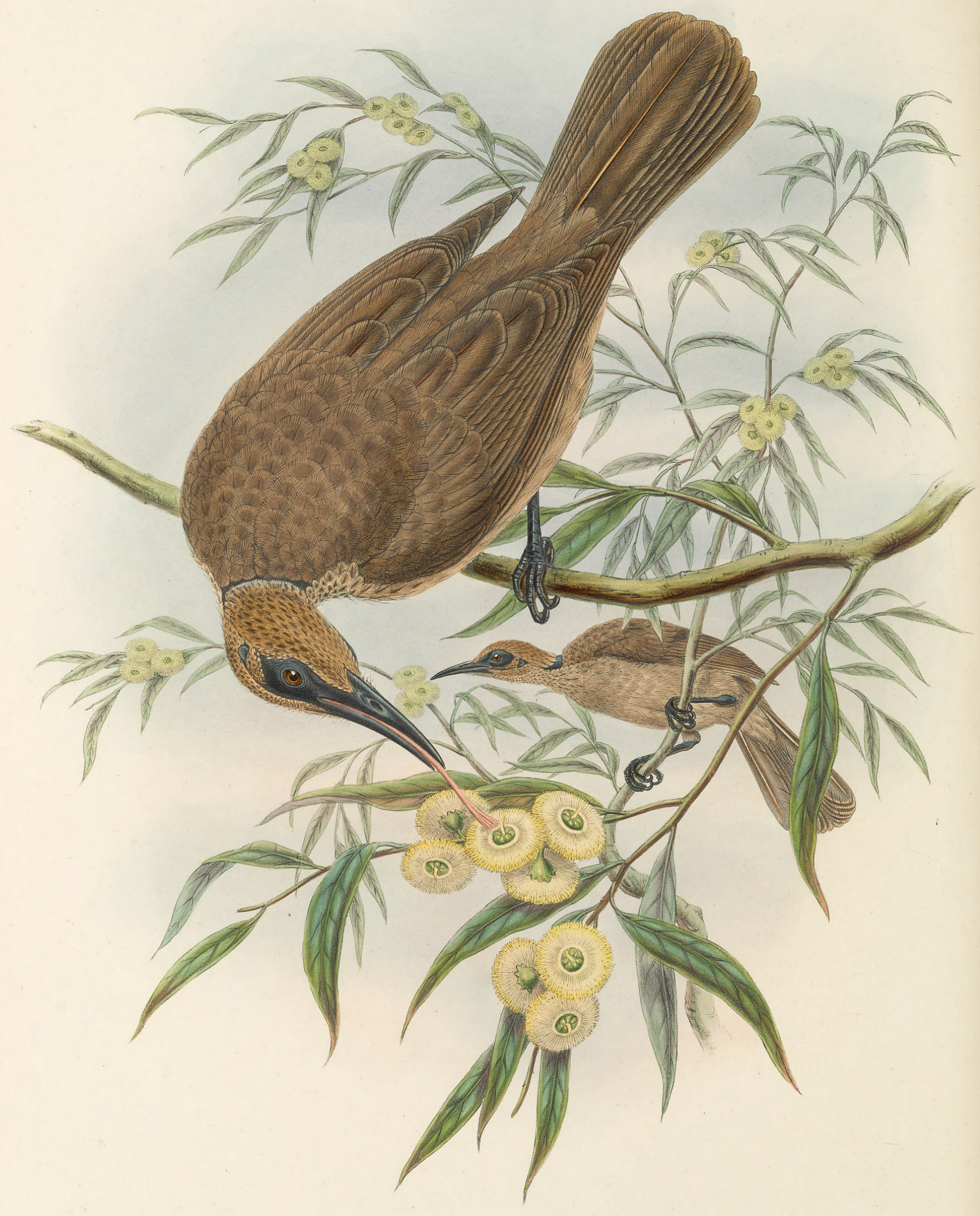




\title{
PHILEMON PLUMIGENIS.
}

\section{Hoary-throated Honey-eater.}

\author{
Tropidorhynchus, n. sp., Wall. Ann. \& Mag. Nat. Hist. 1857, xx. p. 473. \\ Tropidorhynchus plumigenis, Gray, Proc. Zool. Soc. 1858, pp. 174, 191.-Id. Cat. Birds New Guinea, pp. 24, 56 \\ (1859).-Id. Proc. Zool. Soc. 1861, p. 434.-Finsch, Neu-Guinea, p. 165 (1865).-Rosenb. Reis. n. \\ Zuidoostereil, p. 79 (1867).-Meyer, Sitz. k. Akad. Wien, lxx. p. 144 (1874).-Rosenb. Malay Arch. \\ p. $365\left(1878^{-79}\right)$. \\ Philemon plumigenis, Gray, Hand-list of Birds, i. p. 160, no. 2081 (1869).-Salvad. P. Z. S. 1878, p. 88.-Id. Ann. \\ Mus. Civic. Genov. xiv. p. 655 (1879), xvi. p. 79 (1880).-Id. Report Voy. 'Challenger,' ii. p. 70 \\ (1880).-Id. Orn. Papuasia, etc. ii. p. 353 (1881).-Sclater, Proc. Zool. Soc. 1883, p. 51.
}

The Timor Laut examples of this species cannot be said to be strictly identical with the Philemon plumigenis of the Ké Islands, for the head is so much paler brown, more like that of Philemon bouruensis, which it further resembles in having the light mottling above the eye, on the ear-coverts, and sides of face. There can be no doubt that $P$.plumigenis and $P$. bouruensis are very closely allied-so closely, indeed, that it is not easy to assign distinct specific characters to them.

In our article on Oriolus decipiens we have drawn attention to the way in which its plumage mimics that of the present species of Honey-eater, and we would invite our readers to compare the descriptions and figures of the two birds, and to notice how wonderful is the resemblance between them, even to such details as the light hind neck, the appearance of an eyebrow, and the blackish colour of the Oriole's side face, where the bare skin occurs in the Honey-eater. Mr. Forbes tells us that the resemblance is even carried out in their mode of life, and that they are difficult to tell when sitting in the same tree, were it not for the difference of their notes.

We have described here an adult male collected by Mr. Forbes in the T'enimber Islands.

Adult male. General colour above brown, a little paler on the head and mantle; the lower back, rump, and upper tail-coverts darker and more ashy brown; feathers of the crown somewhat lanceolate in shape, with narrow blackish shaft-lines and dusky centres, not sufficiently pronounced to impart a streaked appearance; wing-coverts and quills brown, shaded with ashy on the outer webs of the quills; tail-feathers light brown, rather paler at their ends and crossed with dusky bars under certain lights; sides of the face and region of the eye bare, as well as the ear-spot; ear-coverts and hinder cheeks brown, the fore part of the cheeks washed with hoary whitish; sides of neck hoary grey, extending in a narrow collar round the hind neck; throat and fore neck hoary, the malar line brown; remainder of under surface of body pale ashy brown, the chest with narrow dark-brown shaft-stripes; axillaries and under wing-coverts like the breast, washed with rufous on the edge of the wing; quills dusky brown below; "bill, legs, and feet black; iris dark brown" (H. O. Forbes).

The Plate is drawn from one of Mr. Forbes's specimens; the principal figure is of the natural size. 


\section{$2 \mathrm{BHL}$ Biodiversity Heritage Library}

Gould, John and Sharpe, Richard Bowdler. 1884. "Philemon plumigenis, Hoary-throated Honey-eater [PI. 41]." The birds of New Guinea and the adjacent Papuan islands : including many new species recently discovered in Australia 3(XVI), -. https://doi.org/10.5962/p.322754.

View This Item Online: https://www.biodiversitylibrary.org/item/229963

DOI: https://doi.org/10.5962/p.322754

Permalink: https://www.biodiversitylibrary.org/partpdf/322754

\section{Holding Institution}

Smithsonian Libraries

\section{Sponsored by}

Biodiversity Heritage Library

\section{Copyright \& Reuse}

Copyright Status: Public domain. The BHL considers that this work is no longer under copyright protection.

This document was created from content at the Biodiversity Heritage Library, the world's largest open access digital library for biodiversity literature and archives. Visit BHL at https://www.biodiversitylibrary.org. 